\title{
PENGARUH PENGGANTIAN SEBAGIAN RANSUM BASAL DENGAN MINYAK KELAPA TERHADAP PERFORMA AYAM KAMPUNG SUPER FASE GROWER
}

\author{
Alden S. Bawole, Florencia N. Sompie, Jein R. Leke, Youdhie H.S. Kowel \\ Fakultas Peternakan Universitas Sam Ratulangi Manado 95115
}

\begin{abstract}
ABSTRAK
Penelitian ini bertujuan untuk mengetahui sejauh mana penggantian sebagian ransum basal dengan minyak kelapa terhadap performa ayam kampung super fase grower. Materi yang digunakan 100 ekor ayam kampung super umur 8 minggu dengan rataan berat badan \pm 866,55g. Rancangan yang digunakan adalah Rancangan Acak Lengkap yang terdiri 5 perlakuan dan 5 ulangan. Susunan perlakuan sebagai berikut: $\mathrm{R} 0=100 \%$ ransum basal $(\mathrm{RB})+0 \%$ minyak kelapa, $\mathrm{R} 1=99,5 \% \mathrm{RB}+0,5 \%$ minyak kelapa, $\mathrm{R} 2=99 \% \mathrm{RB}+1 \%$ minyak kelapa, $\mathrm{R} 3=98,5 \% \mathrm{RB}+1,5 \%$ minyak kelapa, $\mathrm{R} 4=98 \% \mathrm{RB}+2 \%$ minyak kelapa. Hasil Penelitian menunjukkan bahwa pengaruh perlakuan berbeda sangat nyata $(\mathrm{P}<0,01)$ terhadap konsumsi ransum. Berdasarkan hasil penelitian dapat disimpulakan bahwa penggunaan minyak kelapa sebagai sumber energi dapat menggantikan ransum basal sampai level 2\% memberikan dampak baik terhadap performa ayam kampung super fase grower.
\end{abstract}

Kata kunci: Performa, minyak kelapa ayam kampung super,

\footnotetext{
*Kosepondensi (corresponding author)
}

Email: rinileke@unsrat.ac.id

\begin{abstract}
THE EFFECT OF BASAL RATIONS REPLACEMENT WITH COCONUT OIL IN RATION ON THE PERFORMANCE OF SUPER NATIVE CHICKEN GROWER PHASE. This study aims to find out the extent of replacement of some basal rations with coconut oil towards the performance of grower phase super native chickens. The material used was 100 super native chicken aged 8 weeks with an average body weight of $\pm 866.55 \mathrm{~g}$. The design used was a Completely Randomized Design (CRD) which consisted of five treatments and five replications. The structure of the treatment was as follows: $\mathrm{R} 0=100 \%$ of basal rations $(\mathrm{RB})+0 \%$ of coconut oil, $\mathrm{R} 1=99.5 \%$ of $\mathrm{RB}+0.5 \%$ of coconut oil, $\mathrm{R} 2=99 \%$ of $\mathrm{RB}$ $+1 \%$ of coconut oil, $\mathrm{R} 3=98,5 \%$ of $\mathrm{RB}+$ $1.5 \%$ coconut oil, $\mathrm{R} 4=98 \%$ of $\mathrm{RB}+2 \%$ of coconut oil. The results of research showed that the treatment was very significantly different $(\mathrm{P}<0.01)$ to the consumption. Based on the results of the study, it can be concluded that the use of coconut oil up to the level of $2 \%$ gave good results on the performance of super native chickens.
\end{abstract}

Keywords: Performance, Coconut Oil, Super native Chicken. 


\section{PENDAHULUAN}

Ayam kampung seperti ayam kedu, ayam nunukan, ayam lampung, dan ayam pelung merupakan unggas lokal yang populasinya tersebar di seluruh wilayah Indonesia. Selain itu ayam kampung juga memiliki peranan yang sangat penting dalam memenuhi kecukupan gizi keluarga, meningkatkan pendapatan keluarga, dan dijadikan sebagai tabungan bagi peternak. Berdasarkan data Badan Pusat Statistik Sulawesi Utara tahun 2018, populasi ayam kampung selama 4 tahun terakhir terus meningkat yaitu di tahun 2015 berjumlah 2.342.204 ekor, 20162.375 .058 ekor, 2017 berjumlah 2.406 .022 dan di tahun 2018 berjumlah 2.448.771 ekor. Untuk memperoleh performa ayam kampung super yang baik dari segi kualitas telur dan daging maka perlu diberikan ransum yang sesuai dengan kebutuhan nutriennya.

Pakan/ransum merupakan salah satu faktor penentu dalam usaha peternakan karena $60-70 \%$ dari biaya produksi. Pemberian ransum pada ayam bertujuan untuk memenuhi kebutuhan nutrien dan energi. Untuk mendapatkan pertumbuhan ayam yang cepat dan produktifitas yang tinggi diperlukan pakan yang berkualitas. Salah satu faktor penting dalam penyusunan pakan ayam adalah kandungan energi disamping protein yang berguna untuk membangun jaringan tubuh.
Pemenuhan nutrien dalam hal ini energi dan protein seringkali menjadi persoalan bagi peternak. Untuk memenuhi kebutuhan energi ayam maka perlu ditambahkan minyak kelapa ke dalam pakan karena minyak kelapa merupakan salah satu bahan sumber energi yang mengandung lemak sebagai sumber energi.

Minyak kelapa memiliki sifat istimewa karena asam lemak jenuh rantai sedang dan asam lemak jenuh rantai pendek yang tinggi nilainya yaitu sekitar 92\% (Aziz et al., 2017). Sifat istimewa pada minyak kelapa menjadikanya lebih baik dari lainnya, hal terebut karena asam lemak jenuh rantai sedang yang mudah diserap tubuh, cepat diubah menjadi energi. Berdasarkan hasil analisa Laboratorium Institut Pertanian Bogor tahun 2018 kandungan nutrien yang terkandung dalam minyak kelapa yaitu lemak 6,22 dan energi metabolis 6334,1 kkal/kg. Rasyaf (1993) menyatakan penggunaan minyak kelapa dalam ransum berkisar $2-6 \%$ dari total ransum. Minyak kelapa adalah bahan sumber energi yang dapat digunakan sebagai sumber energi tambahan untuk ayam kampung super.

Sulawesi Utara merupakan salah satu daerah penghasil kelapa di Indonesia, sehingga daerah ini sering disebut dengan predikat nyiur melambai. Buah kelapa merupakan salah satu komoditas yang menjadi primadona di Sulawesi Utara. 
Tingkat produksi buah kelapa di Sulawesi Utara sangat tinggi, dan produksinya dari tahun ke tahun terus meningkat. (Ditjenbun, 2017) areal perkebunan kelapa Sulawesi Utara seluas 275,656 (Ha) dengan produksi kelapa sebanyak 265,637 ton dan produksi minyak kelapa sebanyak 167,31 juta ton.

Berdasarkan uraian di atas maka telah dilaksanakan penelitian untuk mengatahui apakah penggunaan minyak kelapa sampai dengan level $2 \%$ dapat menggantikan sebagian ransum dan apakah dapat berpengaruh terhadap performa ayam kampung super fase grower.

\section{MATERI DAN METODE PENELITIAN}

\section{Materi Penelitian}

Ternak yang digunakan yaitu 100 ekor ayam kampung umur 8 minggu. Dalam penelitian ini menggunakan kandang sistem baterai dengan ukuran kandang $40 \mathrm{~cm}$ x $60 \mathrm{~cm}$ x $60 \mathrm{~cm}$ sebanyak 25 unit. Susunan ransum penelitian terdiri dari jagung $56 \%$, dedak padi $17 \%$, tepung ikan $13 \%$, bungkil kelapa $13,5 \%$, top mix $0,5 \%$. Level minyak kelapa yang diberikan pada masing - masing perlakuan yaitu: $\mathrm{R} 0=$ Ransum Basal $\quad 100 \%$ (Tanpa Minyak kelapa)

$$
\begin{aligned}
& \text { R1 = Ransum Basal 99,5\% + Minyak } \\
& \text { kelapa , 0,5\% } \\
& \text { R2 = Ransum Basal } 99 \% \text { + Minyak } \\
& \text { kelapa } 1 \% \\
& \text { R3 = Ransum Basal 98,5\% + Minyak } \\
& \text { kelapa } \quad 1.5 \% \\
& \text { R4 = Ransum basal } 98 \%+\text { Minyak } \\
& \text { Kelapa } 2 \% \text {. }
\end{aligned}
$$

Komposisi bahan pakan dan nutrien penyusun ransum dan ransum basal yang digunakan pada penelitian ini dapat dilihat pada Tabel 1 dan Tabel 2

Tabel 1. Kandungan nutrien dan energi metabolis bahan pakan penyusun ransum

\begin{tabular}{lcccccccc}
\hline Bahan Pakan & $\begin{array}{c}\text { Protein } \\
(\%)\end{array}$ & $\begin{array}{c}\text { S.K } \\
(\%)\end{array}$ & $\begin{array}{c}\text { Lemak } \\
(\%)\end{array}$ & $\begin{array}{c}\text { Ca } \\
(\%)\end{array}$ & $\begin{array}{c}\text { P } \\
(\%)\end{array}$ & $\begin{array}{c}\text { Lisin } \\
(\%)\end{array}$ & $\begin{array}{c}\text { Metionin } \\
(\%)\end{array}$ & $\begin{array}{c}\text { EM } \\
\text { Kcal/kg }\end{array}$ \\
\hline Jagung* & 8,85 & 4,38 & 7,71 & 0,02 & 0,03 & 0,02 & 40,2 & 3300 \\
Tepung ikan* & 59 & 0,5 & 9,3 & 5,3 & 2,58 & 4,82 & 2,27 & 2960 \\
Bungkil kelapa* & 21,54 & 15,38 & 12,58 & 0,1 & 0,6 & 0,68 & 0,5 & 1400 \\
Dedak halus* & 9,9 & 12,83 & 6,58 & 0,2 & 1 & 0,57 & 0,22 & 2400 \\
MinyakKelapa** & & & 6,22 & & & & & 6334,1 \\
Top mix & & & & & & & & \\
\hline
\end{tabular}

Sumber: *Nelwan et al. (2019)

**Leke et al. (2019) 
Tabel 2. Komposisi ransum basal serta kandungan nutrient dan energi metabolisnya

\begin{tabular}{lccccccccc}
\hline Bahan Pakan & $\begin{array}{c}\text { Penggunaan } \\
(\%)\end{array}$ & $\begin{array}{c}\text { Protein } \\
(\%)\end{array}$ & $\begin{array}{c}\text { S.K } \\
(\%)\end{array}$ & $\begin{array}{c}\text { Lemak } \\
(\%)\end{array}$ & $\begin{array}{c}\mathrm{Ca} \\
(\%)\end{array}$ & $\begin{array}{c}\mathrm{P} \\
(\%)\end{array}$ & $\begin{array}{c}\text { Lis } \\
(\%)\end{array}$ & $\begin{array}{c}\text { Met } \\
(\%)\end{array}$ & $\begin{array}{c}\mathrm{E} . \mathrm{M} \\
\mathrm{Kcal} / \\
\mathrm{Kg}\end{array}$ \\
\hline Jagung & 56 & 4,63 & 1,93 & 4,32 & 0,01 & 0,17 & 0,13 & 0,11 & 1848 \\
Tepung ikan & 13 & 8,27 & 0,07 & 1,21 & 0,69 & 0,34 & 0,62 & 0,30 & 384,8 \\
Bungkil Kelapa & 13,5 & 2,04 & 2,81 & 1,12 & 0,03 & 0,48 & 0,09 & 0,03 & 408 \\
$\begin{array}{l}\text { Dedak halus } \\
\text { Top Mix }\end{array}$ & 17 & 2,51 & 2,08 & 1,70 & 0,01 & 0,08 & 0,09 & 0,06 & 189 \\
\hline Total & 0,5 & & & & & & & & \\
\hline
\end{tabular}

Tabel 3.Komposisi ransum perlakuan serta kandungan nutrien dan energi metabolis

\begin{tabular}{lccccc}
\hline Perlakuan & $\mathrm{R} 0$ & $\mathrm{R} 1$ & $\mathrm{R} 2$ & $\mathrm{R} 3$ & $\mathrm{R} 4$ \\
\hline Ransum Basal & 100 & 99,5 & 99 & 98,5 & 98 \\
Minyak Krelapa & 0 & 0,5 & 1 & 1,5 & 2 \\
\hline Total & 100 & 100 & 100 & 1000 & 100 \\
\hline Nutrien dan Energi Metabolis & $\mathrm{R} 0$ & $\mathrm{R} 1$ & $\mathrm{R} 2$ & $\mathrm{R} 3$ & $\mathrm{R} 4$ \\
Protein $(\%)$ & 17,45 & 17,36 & 17,28 & 17,19 & 17,10 \\
Lemak (\%) & 8,35 & 8,33 & 8,32 & 8,31 & 8,30 \\
Serat Kasar $(\%)$ & 6,89 & 6,85 & 6,81 & 6,78 & 6,75 \\
Ca $(\%)$ & 0,74 & 0,74 & 0,74 & 0,74 & 0,72 \\
P $(\%)$ & 1,07 & 1,06 & 1,05 & 1,05 & 1,04 \\
Lisin $(\%)$ & 0,94 & 0,94 & 0,93 & 0,93 & 0,92 \\
Metionin $(\%)$ & 0,50 & 0,50 & 0,50 & 0,49 & 0,49 \\
EM (Kcal/Kg) & 2829,8 & 2847 & 2865 & 2882 & 2900 \\
\hline Ketrangn $)$
\end{tabular}

Keterangan: Dihitung berdasarkan Tabel 1 dan Tabel 2.

\section{Variabel yang diukur}

\section{Konsumsi.}

Konsumsi ransum diukur setiap hari berdasarkan selisih ransum yang diberikan dengan sisa ransum.

Konsumsi Ransum =

Ransum yang diberikan (g) - Ransum sisa (g) Jumlah Ayam

\section{Pertambahan Bobot Badan ( PBB )}

Pertambahan berat badan diukur berdasarkan selisih penimbangan bobot badan akhir penelitian dengan bobot badan awal penelitian. Pertambahan Bobot $\operatorname{Badan}(\mathrm{g})=$

$$
\mathrm{BBt}(\mathrm{g})-\mathrm{BBt}-1(\mathrm{~g})
$$

Keterangan:

$$
\begin{aligned}
& \mathrm{PBB}=\text { Pertambahan bobot badan } \\
& \mathrm{BBt}=\text { Bobot badan pada waktu akhir } \\
& \mathrm{BBt}-1=\text { Bobot badan awal } \\
& \mathrm{t} \quad=\text { Kurun waktu satu minggu }
\end{aligned}
$$

\section{Konversi}

Konversi pakan adalah perbandingan antara konsumsi pakan dengan bobot akhir panen. 
Konversi pakan $=$

Konsumsipakan (g)

Pertambahan bobotbadan $(\mathrm{g})$

\section{HASIL DAN PEMBAHASAN}

Data hasil penelitian tentang penggunaan level minyak kelapa sebagai pengganti sebagian ransum basal pada ayam kampung super dapat dilihat pada Tabel 4.

\section{Pengaruh Perlakuan Terhadap Konsumsi Ransum}

Hasil pengamatan pengaruh perlakuan terhadap komsumsi ransum selama penelitian dapat dilihat pada Tabel 4. Data pada Tabel 4 menunjukan bahwa rata-rata konsumsi ransum berkisar antara 47,15-52,59 gram/ekor/hari. Hasil analisis keragaman menunjukkan bahwa ransum perlakuan dengan penggunaan minyak kelapa sebagai pengganti sebagian ransum terhadap konsumsi ransum ayam kampung super fase grower memberikan pengaruh yang berbeda sangat nyata $(\mathrm{P}<0.01)$ antar perlakuan terhadap konsumsi ransum. Hasil uji BNJ menunjukan bahwa perlakuan R0 dan R1 berbeda tidak nyata dengan perlakuan R2 tetapi berbeda sangat nyata dengan perlakuan R3 dan R4. Hasil ini menunjukkan bahwa respon ayam kampung super fase grower terhadap ransum perlakuan dengan menggunakan minyak kelapa tidak sama dengan respon terhadap ransum kontrol (tanpa menggunakan minyak kelapa). Hal ini disebabkan karena kandungan nutrien ransum perlakuan menggunakan minyak kelapa terutama energi ransum lebih tinggi dibandingkan kandungan energi pada ransum control, sehingga berpengaruh nyata lebih rendah. Sanyoto dan Ryanto, (2004) menyatakan bahwa konsumsi ransum ditentukan oleh kandungan energi dalam ransum.

Nilai konsumsi tertinggi terdapat pada perlakuan (R2) 52,59 dan terendah pada perlakuan (R4) 47,15. Nilai konsumsi ransum pada penelitian ini masih dalam kisaran standar konsumsi ransum menurut Sarwono (2003) yaitu untuk ayam usia 2-3-

Tabel 4. Rataan konsumsi, pertambahan bobot badan, dan konversi ransum

\begin{tabular}{lccccc}
\hline \multirow{1}{*}{ Parameter } & \multicolumn{5}{c}{ Perlakuan } \\
\cline { 2 - 6 } & $\mathrm{R} 0$ & $\mathrm{R} 1$ & $\mathrm{R} 2$ & $\mathrm{R} 3$ & $\mathrm{R} 4$ \\
\hline Konsumsi ransum (gram/ekor/hari) & $51,90^{\mathrm{a}}$ & $50,05^{\mathrm{ab}}$ & $52,59^{\mathrm{a}}$ & $48,13^{\mathrm{b}}$ & $47,15^{\mathrm{b}}$ \\
PBB (gram/ekor/hari) & 17,19 & 18,00 & 19,09 & 17,25 & 17,69 \\
Konversi ransum & 3,02 & 2,78 & 2,78 & 2,79 & 2,67 \\
\hline
\end{tabular}

Keterangan : Superskrip yang berbeda pada baris yang sama menunjukan berbeda nyata $(\mathrm{P}<0,01)$. 
5 bulan membutuhkan $46-60$ gram/ekor/hari. Konsumsi ransum dalam penelitian ini lebih rendah dengan yang dinyatakan oleh Lero et al. (2018) bahwa rata-rata konsumsi ayam kampung yang dipelihara secara intensif sebesar 56,13 57,89. Prayogi (2007) menyatakan bahwa konsumsi dipengaruhi oleh kandungan energi. Jika kebutuhan energi telah terpenuhi maka ayam akan berhenti mengkonsumsi ransum. Kebutuhan energi metabolis ayam kampung persilangan untuk fase starter adalah $2.900 \mathrm{kkalME} / \mathrm{kg}$, sedangkan untuk ayam kampung super fase finisher dibutuhkan energi metabolis yang cenderung lebih rendah dari fase starter, dengan demikian ransum dengan level penggunaan minyak kelapa semakin tinggi kandungan energi ransum sebesar 2900 $\mathrm{kkal} / \mathrm{kg}$ berdampak pada menurunnya jumlah konsumsi.

\section{Pengaruh perlakuan terhadap pertambahan bobot badan}

Rataan pertambahan bobot badan yang tercantum pada Tabel 4 berkisar antara 17,19 - 19,09 gram/ekor/hari. Rataan pertambahan bobot badan tertinggi terdapat pada perlakuan R2 dan terendah terdapat pada perlakuan R0. Hasil penelitian ini lebih tinggi dibandingkan dengan hasil penelitian Lero et al. (2018) dimana hasilnya berkisar antara 6,75 14,62 gram/ekor/hari.
Hasil analisis keragaman menunjukaan bahwa setiap jenis perlakuan memberikan pengaruh yang tidak berbeda nyata $(\mathrm{P}>0.05)$ terhadap pertambahan bobot badan. Artinya setiap jenis perlakuan dengan level penggunaan minyak kelapa yang berbeda dapat memenuhi kebutuhan enrgi dan kandungan zat - zat makanan yang dibutuhkan ayam. Anggorodi (1994) menyatakan bahwa kandungan energi ransum menentukan besarnya konsumsi karena ayam kampung merupakan ternak yang mengkonsumsi ransum untuk memenuhi kebutuhan hidup pokok.

Menurut Mokodongan et al. (2017), pertumbuhan dipengaruhi oleh tingkat pemberian makanan, jika makanan yang diberikan cukup dan kandungan nutrien seimbang maka pertambahan bobot ayam akan lebih cepat.

\section{Pengaruh perlakuan terhadap konversi ransum}

Rataan konversi pakan Tabel 4 berkisar antara 2,67 - 3,02. Nilai konversi pada penelitian ini terutama perlakuan penggunaan minyak kelapa pada level $0,5 \%$ - $2 \%$ berada pada kisaran hasil penelitian yang dilaporkan Made et al. (2017) yaitu berkisar antara 2,60 - 2,95 per ekor per hari, kecuali ransum kontrol yaitu 3,02. Rohaeni et al. (2003) dalam penelitian mengatakan minyak kelapa sebesar 2,5\% dalam ransum ayam akan menghasilkan konversi sebesar 
2,26. Artinya nilai konvesi pada penelitian ini masih dalam standar konversi ayam kampung yang baik. Semakin kecil angka konversi ransum berarti semakin efisien ransum tersebut digunakan oleh ternak.

$$
\text { Hasil analisis keragaman }
$$

menunjukaan bahwa perlakuan dalam penelitian dengan menggunakan minyak kelapa sampai tingkat $2 \%$ dalam ransum sebagai pengganti sebagian ransum memberikan pengaruh yang berbeda tidak nyata $(\mathrm{P}>0.05)$ pada tiap perlakuan. Hal ini menunjukkan bahwa penggunaan minyak kelapa sebagai pengganti sebagian ransum sampai dengan level $2 \%$ memberikan pengaruh yang sama terhadap konversi ransum.

\section{KESIMPULAN}

- Berdasarkan hasil penelitian ini dapat disimpulakan bahwa penggunaan minyak kelapa sebagai sumber energi dapat menggantikan ransum basal sampai level $2 \%$ memberikan dampak baik terhadap performa ayam kampung super fase grower.

\section{UCAPAN TERIMA KASIH}

Terima kasih kepada bidang kerja sama Universitas Sam Ratulangi dan Fakultas Peternakan Universitas Padjadjaran yang telah melaksanakan penelitian kerja sama tahun 2018. Terima ksih kepada Rektor Universitas Sam Ratulangi dan ketua LPPM Universitas Sam Ratulangi yang telah mendanai penelitian kerja sama dengan Fakultas Peternakan Universitas Padjadjaran. Kepada Prof. Dr. Ir. Hj. Tuti Wdjastuti, M.S sebagai dosen pembimbing eksternal.

\section{DAFTAR PUSTAKA}

Anggorodi, R. 1994. Ilmu Makanan Ternak Umum. Gramedia Pustaka Utama.Jakarta.

Aziz, T., Yohana Olga dan Ade Puspita Sari. 2017. Pembuatan virgin coconut oil (VCO) dengan metode penggaraman. Jurnal Teknik Kimia 23(2): $129-136$

Badan Pusat Statistik. 2018. http://www.bps.go.id. Tanggal akses 23 November 2019

Direktorat Jenderal Perkebunan. 2017. http://www.ditjen.pertanian.go.id. Tanggal akses 23 November 2019

Lero, A.P., N. P. F. Suryani dan M. Sinlae. 2018. Pengaruh pemberian larva feses sapi terhadap konsumsi ransum ayam buras. Jurnal Nukleus Peternakan 5(2): 149-154.

Leke, J. R., F. N. Sompie. E. Wantasen, T. Widyastuti, E .H. B. Sondakh. 2019. Karakteristik organ bagian dalam ayam buras yang diberi pakan minyak kelapa (Cocos Nucifera) dalam ransum. Zootec 39(2): $233-240$.

Mokodongan, A.R., F. Nangoy, J.R. Leke dan Z. Poli. 2017. Penampilan 
pertumbuhan ayam bangkok starter yang diberi pakan dengan level protein berbeda. Zootek 37(2): 426 $-435$.

Made, L.S., S. Tantalo dan K. Nova. 2017. Performa ayam Kub (Kampung Unggul Balitnak) periode grower pada pemberian ransum dengan kadar protein kasar yang berbeda. Jurnal Riset dan Inovasi Peternakan 1(3): 36-41.

Nelwan, Y., J. R. Leke, F.N. Sompie dan J.T. Laihad. 2019. Pengaruh penggunaan minyak kelapa dalam ransum terhadap bobot badan akhir, bobot dan persentase karkas, serta persentase lemak abdominal pada ayam buras super. Zootec 39(2): 293-301

Prayogi, H.S. 2007. Pengaruh penggunaan minyak kelapa dalam ransum terhadap konsumsi pakan, peningkatan bobot badan, konversi pakan, dan karkas broiler periode finisher. Jurnal Ternak Tropika $7(2): 18-27$.

Rohaeini, E.S., Tri Yuwanta, dan Zuprizal. 2003. Penampilan dan nitrogen ekstra serta kolestrol darah pada ayam broiler yang mendapat pakan all grain dan non all grain pada level protein yang berbeda. Jurnal Peternakan 27(4): 151-160.

Sarwono, B. 2003. Beternak Ayam Buras. Jakarta. Penebar Swadaya.

Sanyoto, J. I. dan J. Riyanto. 2004. Penggunaan minyak kelapa dan lemak sapi sebagai sumber energi ransum broiler. Journal of Indonesian Tropical Animal Agriculture 29(3): 148-155. 